\title{
SOSIALISASI DAN PENDAMPINGAN PENGEMBANGAN BAHAN AJAR IPA BERBASIS MULTI LEVEL REPRESENTASI PADA ALUMNI PENDIDIKAN KIMIA UNIVERSITAS MATARAM
}

\author{
Wildan $^{1 *}$, Dwi Laksmiwati ${ }^{1}$, Jeckson Siahaan ${ }^{1}$, Lalu Rudyat Telly Savalas ${ }^{1}$, Supriadi, Sunniarti Ariani ${ }^{1}$ \\ ${ }^{1}$ Program Studi Pendidikan Kimia, Universitas Mataram. Jalan Majapahit No. 62 \\ Mataram, Indonesia. \\ * Coressponding Author. E-mail: Wildanfkip@unram.ac.id
}

Received: 6 November 2021 Accepted: 4 Februari 2022 Published: 6 Februari 2022

\begin{abstract}
Abstrak
Pembelajaran kimia yang lengkap adalah pembelajaran yang menghubungkan tiga level representasi kimia, yaitu level makroskopik, simbolik, dan submikroskopik. Dengan pembelajaran berbasis multi level representasi, mahasiswa dapat menjelaskan konsep kimia secara ilmiah tanpa ada miskonsepsi. Program ini bertujuan untuk mensosialisasikan dan mendampingi alumni pendidikan kimia yang sudah menjadi guru dalam mengembangan pembelajaran kimia berbasis multilevel representasi sebagai upaya untuk meningkatkan kemampuan siswa dalam menghubungkan tiga level representasi. Ada beberapa tahapan yang dilakukan selama pengabdian, yaitu persiapan, sosialisasi, pendampingan, Workshop hasil kerja peserta, dan monitoring, evaluasi serta pelaporan. semua tahapan dilaksanakan secara daring. Kegiatan ini berjalan dengan lancar sesuai perencanaan dan memberikan hasil positif bagi peserta. Peserta kegiatan sangat antusias mengikuti kegiatan yang dilaksanakan. Materi pengabdian diakui sangat berguna bagi para guru terutama dalam pengembangan dan penggunaan bahan ajar berbasis multi level representasi yang diharapkan dapat membuat siswa memahami kimia melalui tiga level representasi.
\end{abstract}

Kata Kunci: sosialisasi, bahan ajar IPA, multiple representasi

\section{PENDAHULUAN}

Pembelajaran kimia yang lengkap adalah pembelajaran yang menghubungkan tiga level representasi kimia, yaitu level makroskopik, simbolik, dan submikroskopik. Representasi makroskopik diperoleh melalui pengamatan nyata dari suatu fenomena berupa warna, bentuk, dan aroma. Representasi submikroskopik menjelaskan fenomena pada level partikulat. Representasi simbolik diperoleh melalui simbolsimbol level partiulat. Dari ketiga level representasi tersebut, mahasiswa sering kesulitan dalam memahami level submikroskopik karena bersifat abstrak (tidak dapat diobservasi) (Supriadi, dkk, 2018). Pembelajaran kimia diawali dengan mempelajari aspek makroskopik dan simbolik, kemudian diperdalam dengan aspek submikroskopik (Cheng, 2009).

Pembelajaran yang menggunakan bahan ajar berbasis multilevel representasi penting dilakukan untuk memvisualisasikan konsep kimia yang abstrak (Wulandari dkk., 2018; Wati dkk., 2019). Pemahaman seseorang terhadap konsep kimia ditentukan oleh kemampuannya dalam mentransfer dan menghubungkan ketiga level representasi tersebut. Ketidakmampuan siswa dalam merepresentasi kan kimia pada level submikroskopik dapat menghambat kemampuannya dalam memecahkan masalah kimia yang berkaitan dengan level makroskopik maupun simbolik (Sunyono, 2013; Sagita dkk., 2017).

Berdasarkan observasi yang dilakukan oleh peneliti, sebagian besar guru belum mengembangkan bahan ajar berbasis multilevel representasi. Pembelajaran yang dilakukan tidak menghubungkan tiga level representasi dalam menjelaskan konsep, sehingga pemahaman siswa menjadi tidak lengkap. Ketika menggunakan metode praktikum, mereka hanya menghubungkan level makroskopik dengan simbolik, sedangkan ketika mempelajari teoriteori, mereka hanya menghubungkan level submikroskopik dengan simbolik. Menurut Sukmawati (2019), hal ini yang menyebabkan mahasiswa tidak mampu menghubungkan antara level makroskopik dengan submikroskopik. 
Permasalahan ini dapat diselesaikan dengan memberikan pengetahuan dan pembinaan kepada semua guru kimia tentang pengembangan bahan ajar berbasis multilevel representasi. Hal ini dilakukan agar mereka menerapkannya di sekolah masing-masing. Alumni pendidikan kimia FKIP Universitas Mataram yang sudah menjadi guru merupakan salah satu tujuan pengabdian yang penting karena mereka tersebar di semua sekolah di NTB.

Berdasarkan hal tersebut, pelaksana tertarik untuk melakukan sosialisasi dan pendampingan pengembangan bahan ajar berbasis multilevel representasi untuk Alumni Pendidikan Kimia FKIP Universitas Mataram. Kegiatan ini merupakan bentuk intervensi dalam upaya meningkatkan kemampuan siswa dalam menghubungkan tiga level representasi kimia.

\section{METODE PELAKSANAAN}

Untuk mencapai target, maka ada beberapa tahapan implementasi program pengbadian yaitu:

1. Tahap Persiapan. Beberapa kegiatan yang dilakukan pada tahapan ini meliputi: menyusun ToR (Term of Reference), identifikasi calon peserta, workshop internal tim pengabdian (seperti penentuan waktu pelatihan, tempat, materi pelatihan), pengurusan izin melaksanakan kegiatan pengabdian.

2. Tahap sosialisasi. Kegiatan yang dilakukan pada tahapan ini antara lain memberikan sosialisasi kepada Alumni Pendidikan Kimia FKIP Univeristas Mataram. Materi yang dibahas yaitu cara pengembangan bahan ajar berbasis multi level representasi. tahap sosialisasi dilaksanakan secara daring menggunakan flatform google meet.

3. Tahap pendampingan. Pada tahap ini dilakukan pendampingan terhadap kerja kelompok peserta dalam menyelesaikan tugas berkaitan dengan pengembangan bahan ajar berbasis multi level representasi. kegiatan ini juga dilakukan secara daring.

4. Workshop hasil kerja guru. Pada tahap ini dilakukan workshop untuk melihat hasil kerja guru-guru berkaitan dengan pengembangan bahan ajar berbasis multi level representasi yang dilaksanakan secara daring.

5. Tahap Monitoring, Evaluasi dan Pelaporan. Kegiatan pada tahapan ini dimaksudkan untuk mendeteksi dan mengevaluasi keseluruhan kegiatan pengabdian sehingga dapat diketahui hasil, teridentifikasi permasalahan/kendala yang muncul, faktor yang mendukung dan menghambat serta solusi pemecahannya. Keseluruhan kegiatan selanjutnya dibuat dalam bentuk laporan akhir kegiatan pengabdian.

\section{HASIL KEGIATAN}

\section{Deskripsi Pelaksanaan Kegiatan}

Kegiatan sosialisasi pengembangan bahan ajar IPA berbasis multi level representasi ini dilaksanakan selama sehari, pada hari Kamis, tanggal 16 September 2021 secara daring menggunakan google meet, diikuti oleh 44 orang alumni S-1 Pendidikan Kimia, FKIP, Universitas Mataram, dan dihadiri oleh semua anggota tim.

Kegiatan diawali pada jam 09.00 dengan acara pembukaan yang disampaikan oleh Ketua Tim (Dr. H. Wildan, M.Pd). Pada acara pembukaan tersebut disampaikan tentang latar belakang, tujuan, manfaat, dan rangkaian acara pada kegiatan sosialisasi/pendampingan. Setelah diselingi dengan acara kudapan/coffee break, acara dilanjutkan dengan penyajian materi yang pertama, yaitu tentang TPACK (Technological Pedagocal Content Knowledge) oleh Ketua Tim. Adapun pokok materinya meliputi karakteristik siswa abad 21, keterampilan abad 21, konsep dan komponen TPACK, dan kemampuan TPACK, kemudian Tanya jawab.

Kegiatan selanjutnya adalah penyampaian materi dan diskusi tentang Metode Pengembangan Bahan Ajar yang dipandu oleh Dra. Hj. Dwi Laksmiwati, M.Sc. dan Dr.rer.nat. Lalu Rudyat Telly Savalas. Adapun pokok-pokok materinya meliputi latar belakang keharusan guru dalam mengembangkan bahan ajar sesuai dengan kebutuhan siswa, bagaimana mengembangkan bahan ajar, dan metode pengembangannya. Pada kegiatan ini diakhiri dengan diskusi dan tanya jawab tentang bahan ajar pada masing-masing bidang studi IPA. Setelah dilaksanakan 2 kegiatan tersebut di atas, peserta dan narasumber istirahat selama 90 menit untuk sholat dan makan siang.

Pada sesi ke 3, dimulai jam 14.00 - 16.00 disampaikan materi tentang Pengembangan Bahan Ajar IPA Berbasis Multi Level Representasi yang dipandu oleh Supriadi, M.Pd. Pada sesi ini disampaikan tentang tiga level representasi, yaitu level makroskopik, simbolik dan submikroskopik, serta pentingnya menghubungkan ketiga level representasi. Selain 
itu, disampaikan juga tentang pengembangan bahan ajar yang memuat ketiga level representasi tersebut menggunakan media flipbook secara daring di alamat web https://flippingbook.com. Selanjutnya, peserta diminta untuk mencoba mengembangkan bahan ajar untuk satu sub-topik sederhana yang menghubungkan tiga level representasi secara berkelompok yang beranggotakan 4 orang. Bahan ajar yang sudah dikembangkan oleh peserta sudah bagus karena ada yang menggunakan media flipbook yang mana di dalam media tersebut bisa memasukkan video yang menggambarkan makroskopik dan animasi yang menggambarkan level submikroskopik.

Sebelum mengakhiri kegiatan, ketua tim meminta peserta untuk menyempurnakan bahan ajar yang sudah dimulai agar bisa diterapkan dalam pembelajaran. Peserta juga diharapkan mengembangkan bahan ajar untuk topik-topik lain.

\section{Evaluasi Hasil}

Evaluasi dilakukan dengan cara observasi dan menggunakan kuesioner. Observasi selama acara berlangsung, sedangkan pengisian kuesioner dilakukan setelah acara selesai untuk mengetahui tanggapan peserta terhadap kegiatan sosialisasi/ pendampingan dan evaluasi pembelajaran, serta untuk mengetahui penerimaan peserta terhadap kegiatan tersebut. Instrumen yang digunakan berupa kuesioner yang terdiri dari 5 (lima) komponen, yaitu (1) materi sosialisai, (2) hasil, (3) tindak lanjut, (4) fasilitator, dan (5) waktu pelaksanaan.

Berdasarkan hasil observasi, semua peserta sangat antusias dalam mengikuti acara. hal tersebut terlihat dari keaktifan mereka dalam bertanya dan menyelesaikan tugas yang diberikan. Ada 5 peserta yang bertanya dan ada 3 peserta yang menanggapi. Selain itu, semua peserta secara berkelompok aktif dalam mengerjakan tugas yang diberikan.

Berdasarkan hasil kuesioner, terlihat bahwa mahasiswa sangat tertarik terhadap materi yang diberikan karena materi tersebut mereka butuhkan dalam pembelajaran di kelas. Para peserta berniat untuk menerapkannya di sekolah masing-masing. "Kegiatan sosialisasi ini menambah wawasan saya tentang pengembangan bahan ajar, saya akan mempelajari lebih lanjut, dan akan menerapkannya di sekolah" kata Amanda Eki Wirya Sati, S.Pd., salah satu peserta sosialisasi yang mengajar di SMAN 1 Gangga, KLU. Selain Amanda Eki Wirya Sati, S.Pd., Pernyataan selaras juga disampaikan oleh Erna Rofiqa, S.Pd., guru di MAN 2 Mataram, yang mengatakan bahwa materi sosialisasi yang disampaikan membuka mindset sebagai pendidik untuk terus mengupdate diri, menyesuaikan diri dengan kemajuan teknologi, kemudian memanfaatkannya dalam bidang pendidikan.

Berdasarkan pernyataan-pernyatan yang diberikan oleh peserta menunjukkan bahwa materi yang disampaikan bermanfaat dan mampu menggugah mereka untuk terus mengembangkan diri. Pengembangan diri yang ingin mereka lakukan adalah mempelajari lebih lanjut tentang teknologi pembelajaran, penguasaan aplikasi pembelajaran, dan kemampuan dalam mengembangkan bahan ajar berbasis teknologi baru dan berbasis multi level representasi. Selain pengembangan diri, mereka juga ingin mengembangkan bahan ajar berbasis multi level representasi untuk topik-topik lain dan menerapkannya dalam pembelajaran di kelas. Dengan kata lain, peserta bersikap positif terhadap materi-materi yang disempaikan pada kegiatan ini.

\section{Faktor Pendukung}

Kegiatan sosialisasi dan pendampingan ini berjalan dengan baik karena didukung oleh beberapa faktor: 1) Ketersediaan sarana dan prasarana yang memadai terutama sumber belajar yang dapat di akses dengan mudah melalui internet. Sarana penunjang lainnya seperti laptop, jaringan internet, dan kuota tersedia sehingga sangat membantu kelancaran kegiatan. 2) Semua anggota tim peneliti hadir tepat waktu dan memberikan file materi kepada peserta, sehingga kegiatan ini dapat berjalan dengan baik. 3). Antusiasme peserta dalam menghadiri kegiatan cukup tinggi.

\section{Faktor Penghambat}

Secara umum tidak ada faktor penghambat dalam kegiatan yang telah dilangsungkan, hanya masalah kecil seperti kontrol terhadap partisipasi peserta, karena kegiatan dilaksanakan secara daring.

\section{KESIMPULAN DAN SARAN}

\section{Kesimpulan}

Kegiatan "sosialisasi dan pendampingan pengembangan bahan ajar berbasis multi level 
representasi" berjalan dengan lancar sesuai perencanaan dan hasil positif bagi peserta, baik tentang materi sosialisasi/pendampingan, pemahaman, kegunaan dan tindak lanjut yang akan dilakukan peserta. Peserta kegiatan hadir tepat waktu dan sangat antusias mengikuti kegiatan yang dilaksanakan.

Materi pengabdian diakui sangat berguna bagi para guru terutama dalam pengembangan dan penggunaan bahan ajar berbasis multi level representasi yang diharapkan dapat membuat siswa memahami kimia melalui tiga level representasi. Keberhasilan pengenalan bahan ajar berbasis multi level representasi ini dapat dilihat dari perubahan sikap guru dalam mengembangkan diri untuk terus meng-update kemampuannya.

\section{Saran}

Kegiatan pengabdian ini perlu ditindaklanjuti karena dipandang sangat bermanfaat bagi guru dalam mengembangkan dan menerapkan bahan ajar berbasis multi level representasi. Oleh karena perkembangan zaman yang begitu pesat, dosen dan guru harus mengembangkan bahan ajar secara terus-menerus dengan pendekatan yang memungkinkan siswa berlatih mengembangkan kemampuan menghubungkan tiga level representasi.

\section{DAFTAR PUSTAKA}

Sagita, R., Azra, F., \& Azhar, M. (2017). Pengembangan Modul Konsep Mol Berbasis Inkuiri Terstruktur Dengan
Penekanan Pada Interkoneksi Tiga Level Representasi Kimia Untuk Kelas X Sma. Jurnal Eksakta Pendidikan (JEP), 1(2), 25-32.

Sukmawati, W. (2019). Analisis level makroskopis, mikroskopis dan simbolik mahasiswa dalam memahami elektrokimia. Jurnal Inovasi Pendidikan IPA, 5(2), 195-204.

Sunyono, S., Leny, Y., \& Muslimin, I. (2013). Efektivitas model pembelajaran berbasis multipel representasi dalam membangun model mental mahasiswa topik stoikiometri reaksi. Journal Pendidikan Progresif, 3(1), 65-79.

Supriadi, S., Ibnu, S., \& Yahmin, Y. (2018). Analisis Model Mental Mahasiswa Pendidikan Kimia Dalam Memahami Berbagai Jenis Reaksi Kimia. Jurnal Pijar Mipa, 13(1), 1. https://doi.org/10.29303/jpm.v13i1.433

Wati, F. S., Lathifa, U., \& Udaibah, W. (2019). Pengembangan Modul Kesetimbangan Kimia Berbasis Unity Of Sciences (Uos) dan Multilevel Representasi. THABIEA: JOURNAL OF NATURAL SCIENCE TEACHING, 2(2), 70-77.

Wulandari, C., Susilaningsih, E., \& Kasmui, K. (2018). Estimasi validitas dan respon siswa terhadap bahan ajar multi representasi: definitif, makroskopis, mikroskopis, simbolik pada materi asam basa. Phenomenon: Jurnal Pendidikan MIPA, 8(2), 165-174. 